\title{
Het beeldscherm als blikverruimer: een speelse respons op de uitdagingen van online therapie voor kinderen en gezinnen
}

\author{
Sabine Vermeire · Luc Van den Berge
}

\section{Samenvatting}

De groeiende vraag naar online therapie voor kinderen, jongeren en gezinnen tijdens de coronapandemie heeft ons voor nieuwe uitdagingen gesteld. Daardoor zagen we ons genoodzaakt om buiten de gebaande paden te treden. Dit artikel is een verkenning van nieuwe ideeën voor online vormen van systeemtherapie en narratieve therapie. Het laat zien hoe speelsheid tijdens online sessies leidt tot nieuwsgierigheid, levendigheid en betrokkenheid, en vice versa. In onze optiek is speelsheid een tegengif tegen therapeutische valkuilen en is het een inspiratiebron waarmee we weerstand kunnen bieden aan het gevaar van reductionisme, dat juist bij online therapie op de loer ligt. Speelsheid biedt als het ware de stapstenen voor het serieus exploreren en delen van ervaringen, verhalen en betekenissen, van waaruit creatievere ideeën en een diepgaander begrip kunnen ontstaan. Speelsheid verschaft ook nieuwe manieren om met elkaar om te gaan, zowel voor de gezinsleden onderling als voor gezin en therapeut. En ten slotte geeft speelsheid ook de mogelijkheid om verbindingslijnen tussen sessies te trekken, waardoor er een gevoel van continuïteit kan ontstaan. We belichten in dit artikel verschillende casussen om te laten zien hoe we te werk zijn gegaan.

\footnotetext{
Widening the Screen: Playful Responses tot Challenges in Online Therapy with Children and Families. Journal of Family Therapy, 2021, 0: 1-2, https://doi.org/10.1111/1467-6427.12326 (C) 2021 Association for Family Therapy and Systemic Practice in the UK. Vertaling: Elisa Taalservice, Den Haag.

S. Vermeire $(\bowtie)$

Interactie-Academie vzw, Van Schoonbekestraat 33, Antwerpen, België

e-mail: sabine.vermeire@iaac.eu

L. Van den Berge

Faculteit Psychologie en Pedagogische wetenschappen, Department of Experimental Clinical and Health Psychology, Universiteit Gent, Visitatiestraat 97, 9040 Gent, België
} 


\section{Belangrijke punten voor de praktijk}

Speelsheid in online therapie, in de vorm van een bepaalde sfeer, houding of interventie, leidt tot nieuwsgierigheid, levendigheid en betrokkenheid (en vice versa) en biedt tegelijkertijd nieuwe therapeutische mogelijkheden.

Door een breed systemisch perspectief te behouden en door figuren uit het echte en denkbeeldige netwerk bij de sessies te betrekken, wordt tegenwicht geboden aan het gevaar van reductionisme in online therapie.

Een speels gebruik van de online opties zorgt voor nieuwe relationele patronen, niet alleen tussen de gezinsleden onderling, maar ook tussen het gezin en de therapeut.

\section{Inleiding: de uitdagingen'}

In de verschillende lockdown-perioden door COVID-19 hebben veel therapeuten en cliënten hun toevlucht moeten nemen tot online behandeling, als de enig overgebleven mogelijkheid van gezinstherapie. Zowel de cliënten als de behandelaars hebben hun comfortzone moeten verlaten en hebben een onbekend en oncomfortabel terrein moeten betreden (Wilson 2007). Als aan gezinstherapeuten gevraagd wordt om de ethische problemen en de nadelige kanten van online sessies te benoemen, blijkt dat ze zich vooral zorgen maken over de impact op de therapeutische relatie (Hertlein et al. 2015, pag. 7-8). Bij online therapie zouden mensen immers belangrijke aspecten missen in de ervaring van onderlinge interacties, mede door de afwezigheid van lichaamstaal en de onmogelijkheid van een fysieke opstelling.

Juist deze zorgen zijn onze grootste uitdagingen geworden, nadat COVID-19 ons gedwongen heeft om online te gaan. De meest in het oog springende uitdaging is de volgende

Op de eerste plaats is de therapeutische ruimte een probleem. Een behandeling uitvoeren in twee (of meer) verschillende, van elkaar gescheiden ruimten, met het computerscherm als digitale verbinding, heeft vele gevolgen. De therapeut treedt binnen bij de cliënten thuis, in hun vertrouwde dagelijkse omgeving, en de sessies kunnen onderbroken worden door broertjes en zusjes of andere 'stoorzenders'.

Ten tweede heeft online therapie een sterk bepalende, disciplinerende uitwerking op onze lichamelijke interacties, waardoor die een andere, minder actieve vorm aannemen. Alle deelnemers moeten immers stil zitten voor de webcam en praten tegen het scherm. Normale interacties, zoals met elkaar kletsen of lachen, zijn simpelweg onmogelijk, behalve voor de mensen die naast elkaar voor hetzelfde scherm zitten. Verder hebben de gesprekken minder 'body', in de betekenis die Shotter (2012) aangeeft als hij zegt dat we anderen beïnvloeden en door anderen

\footnotetext{
${ }^{1}$ Onze bijzondere dank gaat uit naar Jill Geese, die ons in de eerste maanden van de COVID-19-periode heeft geholpen door deze ideeën mede te ontwikkelen en te onderzoeken, zowel in haar lessen als in haar therapeutische werk.
} 
beïnvloed worden via ons lichaam. Daardoor komt ook het gevoel van 'samen zijn' minder snel tot stand. Dat geldt niet alleen voor therapeut en de cliënt, maar ook voor de cliënten onderling, met name als zij zich in verschillende kamers bevinden, achter verschillende beeldschermen. Er is letterlijk geen ruimte voor de natuurlijke, soms een beetje 'rommelige' manier waarop gezinsleden elkaar normaal gesproken ondersteunen of tegenspreken tijdens de sessies.

Ten derde zijn de cliënten ook meer geneigd om alleen te vertrouwen op de woorden, waardoor onze gesprekken zich algauw beperken tot een uitwisseling van frasen, en onze vragen op een 'verhoor' kunnen gaan lijken.

Verder willen we benadrukken dat het kijken naar een beeldscherm onze blik behoorlijk kan vernauwen. Immers, wat we op het scherm zien wordt al gauw de enige context van betekenis, waardoor hypothesen of verklaringen vanuit een bredere, minder zichtbare context niet zo snel aan het licht komen. Vanuit systemisch perspectief kan dit worden beschouwd als een groot risico van beeldschermtherapie.

We hebben echter besloten om hier geen zogeheten 'oneerbiedige' (Cecchin 1987; Cecchin et al. 1992) houding aan te nemen tegenover de problemen en vermeende beperkingen van online therapie. We voelen ons daarbij gesteund door bevindingen uit een recent overzichtsartikel (Simpson et al. 2020) die in tegenspraak zijn met de - door vele therapeuten gedeelde - verwachting dat online therapie de werkrelatie en de behandeluitkomsten zou schaden. Uit de bestudeerde studies blijkt namelijk op goede bewijsgronden dat online therapie juist een krachtig middel is dat extra mogelijkheden biedt voor zelfexpressie, verbinding en intimiteit. De onderzoekers geven aan dat er sprake is van een neutralere therapeutische 'ruimte' die cliënten veelzijdige kansen biedt op het ervaren van zelfbewustzijn, creativiteit en betrokkenheid, en die ook een groter gevoel van controle over de eigen ervaring met zich mee kan brengen.

We hebben inspiratie geput uit de woorden van Koestler over creativiteit:

'De creatieve daad (...) schept niet iets uit het niets; zij ontdekt, selecteert, hergroepeert, combineert en synthetiseert bestaande feiten, ideeën, mogelijkheden, bekwaamheden. Hoe bekender de onderdelen, des te opmerkelijker het nieuwe geheel.' (1964, pag. 120)

Volgens ons biedt speelsheid de kans om negatieve gedachten en vooropgezette denkbeelden achter ons te laten, doordat speelsheid ons uitnodigt nieuwsgierig te zijn en ons in staat stelt om nieuwe therapeutische routes samen te stellen uit alle puzzelstukjes die we voor ons hebben liggen. We beschouwen speelsheid als een sfeer, houding of stemming die in de therapeutische ruimte kan worden opgeroepen, en die zowel therapeuten als cliënten de gelegenheid geeft om te knutselen en te 'kokkerellen' met de ingrediënten die tot hun beschikking staan, en om van daaruit iets nieuws te creëren, zelfs nu de omstandigheden ons tot achter onze beeldschermen terugdringen.

In onze ogen is speelsheid niet zozeer een speciale kwaliteit die door de therapeut inzetbaar is, maar gaat het om de vrijheid en bereidheid om van alles op te pakken wat zich tijdens een sessie zoal voordoet, zoals bepaalde metaforen die door een cliënt worden geuit, bepaalde gedachten die de therapeut zelf te binnen 
schieten, of dingen (wat dan ook) die op het scherm te zien zijn. Uiteraard hebben we vanuit onze achtergrond en ervaring met de systemische en narratieve benadering van therapie al een aardige voorraad ingrediënten tot onze beschikking, maar het allerbelangrijkste is dat we zorgvuldig hebben geluisterd naar alles wat een kind of een gezin tijdens de online sessies te berde bracht, en wat als aanknopingspunt zou kunnen dienen voor creativiteit of 'geleide improvisatie' (Madsen en Gillespie 2014). We willen graag benadrukken dat de verslagen die we hier presenteren een stuk minder rommelig zijn dan de werkelijk gevoerde gesprekken. We kregen bijvoorbeeld geregeld te maken met technische probleempjes, want niet alle gezinnen beschikten over een goede internetverbinding.

\section{Startfase: twee 'online' verhalen}

Efecan ( 8 jaar) en zijn jongere broertje wonen bij pleegmoeder Cindy, die tevens hun grootmoeder is van moederskant. De vader zit gevangen en de moeder bevindt zich in een psychiatrische instelling. Vóór de pandemie heb ik met Cindy en Efecan al meerdere keren een gesprek gevoerd over de driftbuien van de jongen en over de gevoelens die de afwezigheid van de ouders bij hem oproepen. Als we beginnen aan ons eerste online gesprek, zit Efecan in de woonkamer aan tafel, met voor zich een hele collectie Star Wars-ruimteschepen van lego. Op de achtergrond is duidelijk te horen dat Cindy een woordenwisseling heeft met het kleine broertje.

Jimmy (17 jaar) woont nu twee maanden in een kleine studioflat in het centrum van de stad. Voordien heeft hij in een instelling gewoond waar hij via de kinderrechter geplaatst was. Aan het begin van ons eerste online gesprek verschijnt Jimmy met ontbloot bovenlichaam en zegt dat hij bezig was aan een 'stevige work-out om niet gek te worden'. Ik zie ondertussen dat de keuken achter hem een bende is.

\section{Afspraken maken over de online werkrelatie}

Alles wat er in een therapie gaat gebeuren, wie we zullen zijn voor elkaar, wat we zullen doen en waar we over gaan praten, en wat de belangrijkste doelen van onze gesprekken zullen zijn, dit alles is onderwerp van gesprek in talloze dialogen met andere betrokkenen en wordt daarbij gekleurd door vele 'vanzelfsprekende' ideeën en overtuigingen (Madsen 2007). Deze inkleuring is al aan de gang voordat de eerste online kennismaking heeft plaatsgevonden. En als we elkaar dan uiteindelijk online ontmoeten, is het risico groot dat we door deze vooroordelen beperkt worden, en dat er, na alle voorafgaande discussies, een heel mager probleemverhaal overblijft. Het kind heeft een bepaald idee van wat er moet gebeuren, de ouders hebben bepaalde opvattingen over wat en hoe ze iets willen presenteren via het scherm, en zelfs de therapeut kan zich geneigd voelen om dingen volgens een vooropgesteld stramien uit te voeren. We zijn erachter gekomen dat het online veel lastiger is om hierover (opnieuw) afspraken te maken dan in een face-to-face gesprek. Immers, vanaf het moment dat we onze laptop openklappen lijken we te belanden we in een cleane, formele en statische omgeving, die vereist dat we snel en zonder veel omhaal 'to the point' komen. 
De vraag is dus hoe we een online omgeving kunnen creëren die uitnodigt tot medewerking, nieuwsgierigheid en speelsheid, en - belangrijker nog - die bijdraagt aan het opbouwen van een werkrelatie (Carr 2012, pag. 237). We hebben gemerkt dat we vanaf het begin een grotere betrokkenheid kunnen bereiken door van tevoren een e-mailbericht te sturen waarin het kind of de jongere en de ouders of verzorgers benaderd worden als actieve deelnemers in het op handen zijnde therapeutische proces.

\section{Beste Efecan en Cindy,}

Hierbij nodig ik jullie uit voor onze afspraak van aanstaande maandag. Kunnen jullie van tevoren papier en potloden klaarleggen, en ook een rode kaart of een ander rood object? Je mag ook gerust knuffels, speelgoedauto's, speelgoeddieren, legoblokjes (voor zover beschikbaar) bij de hand houden, maar dat hoeft niet. Zorg ook voor een fijne plek om te zitten. En misschien kun je er vast over nadenken of er iemand is die je graag mee wilt laten luisteren op de achtergrond, of iemand die je graag mee wilt laten doen aan het gesprek. Als er vragen of onderwerpen zijn die je al in gedachten hebt en die je graag wilt bespreken, schrijf die dan van tevoren op. Ik kijk ernaar uit jullie online te ontmoeten, en hoop dat we er samen een fijn gesprek van kunnen maken. Hartelijke groet, $N$.

We vinden het belangrijk dat de kinderen (of jongeren) zelf als eerste de kans krijgen om hun verhaal te doen en over hun ervaringen te vertellen. We willen dat ze een actieve rol hebben en zelf kunnen kiezen welke kant het gesprek op gaat. Om die reden hebben we gevraagd om een rode kaart of ander rood object klaar te leggen. Dit rode object kunnen ze in beeld brengen als we een vraag stellen die ze niet willen beantwoorden, als we een onderwerp aankaarten waar ze liever niet over praten, of als ze zich niet prettig voelen over de wending die het gesprek neemt. We doen ook altijd een try-out met het rode object, zodat het kind het gevoel krijgt een sturende rol te hebben binnen de context van onze samenwerking. We willen daarmee ook bereiken dat het kind meteen merkt dat we het serieus nemen.

Als we al een paar online gesprekken achter de rug hebben, begint Efecan er een spel van te maken om me elke keer te verrassen met een ander rood object in beeld, bijvoorbeeld zijn rode Londense dubbeldekkerbus, een rood kussentje in de vorm van een hart, of zijn rode voetbal.

We zorgen ook voor een sfeer met veel feedbackmogelijkheden (Rober et al. 2020), door middel van stroken gekleurd papier (groen, geel, rood) of emoticons, waardoor we voorkomen dat we verstrikt raken in een verbale pingpongsessie zonder emotionele lading, of in een situatie waarin kind en gezin het idee krijgen in een verhoor te zijn beland. Het is ook belangrijk om op voorhand af te spreken wat te doen als het kind of de volwassene van streek zou raken, zou gaan huilen, of boos of emotioneel zou worden. Is het een goed idee om dan even te pauzeren? Of toch maar liever gewoon te wachten tot het over is? Dit geeft de therapeut de gelegenheid om te weten te komen hoe het kind, of iemand anders binnen het gezin, getroost kan worden. Daarnaast dient ons verzoek om gekleurde objecten klaar te leggen, zoals gekleurde pennen, speelgoed of boetseerklei, om te benadrukken dat het niet alleen om een 'praatsessie' zal gaan, maar dat het kind, en eventueel ook anderen uit het gezin, er actief bij betrokken zullen zijn. Zo stimuleren we 
'spreken door doen' ('language in action', Wilson 2005) en creëren we ook meer levendigheid en beweging in de woorden en gedachten die ons via het scherm bereiken.

\title{
De fase van 'online landen'
}

Bij digitale therapie ontbreken enkele van de vanzelfsprekende, vertrouwde en meer informele 'rituelen' die in normale omstandigheden bijdragen aan het creëren van een behandelcontext, zoals: de gang naar het gezondheidscentrum, het verblijf in de wachtkamer, het verzoek aan de gezinsleden om plaats te nemen, de vraag wat ze willen drinken, enzovoort. Daarentegen treedt de online behandelaar binnen in het dagelijks leven en in de privévertrekken van de cliënt. Dit kan voelen als een inbreuk, maar tegelijkertijd krijgen de kinderen of jongeren de kans om als gastheer of gastvrouw op te treden en de therapeut rond te leiden in de eigen dagelijkse realiteit. Als zij dingen kunnen presenteren die voor hen belangrijk zijn, dan kunnen ze op die manier laten zien dat ze in hun wereld de experts zijn.

\begin{abstract}
Efecan openbaart mij al zijn kennis over Star Wars-ruimteschepen en voor ik het goed en wel in de gaten heb, loopt hij met de tablet rond om me zijn huis te laten zien. Ik vraag hem om even te wachten, want ik weet niet of zijn pleegmoeder wel zo blij is met deze rondleiding. Verder houd ik in mijn achterhoofd dat ze in een luide woordenwisseling was gewikkeld met het jongere broertje en dat het misschien niet de bedoeling was dat ik daar getuige van ben.
\end{abstract}

Het idee dat we ons als therapeuten moeten realiseren dat we te gast zijn in de wereld van de cliënt (Anderson 2007) heeft ons ervan doordrongen dat we terughoudend moeten zijn met commentaar op wat we online zien; dat we altijd eerst toestemming moeten vragen.

'Sorry, maar ik zie dat je keuken eruitziet of er een storm heeft gewoed. Vind je het goed dat ik dat kan zien? Vind je dat wel oké?'

Door ons aan het begin van het gesprek te verbeelden dat we eerst moeten 'landen' en dat we 'omtrekkende bewegingen moeten maken' om te bepalen of de landingsplek veilig is, voorkomen we dat we meteen in specifieke probleemverhalen duiken en worden we aangemoedigd om een brede, systemische blik te behouden. Daarbij zijn we op zoek naar constructieve relaties, en gebieden die veilig of veerkrachtig zijn (Rober 1999; Wilson 2005), zoals bijvoorbeeld verhalen uit de persoonlijke of relationele context, waarin mensen niet gedefinieerd worden door hun problemen of belemmeringen, maar waar ze tevoorschijn komen als actieve deelnemers in hun eigen leven, hun relaties en hun gemeenschap (Vermeire 2020).

De metafoor van landen op een onbekend vliegveld in een onbekend gebied heeft ons hierbij geholpen. Dit beeld wekt nieuwsgierigheid op en stimuleert om de omgeving af te tasten en 'landingsopties' in kaart te brengen voordat het 'echte werk' begint. Ook hebben we geleerd om ons te realiseren dat het decor dat we te zien krijgen op elkaars beeldschermen van invloed is op onze gesprekken en 
nieuwe wegen voor ons kan openen. Zo kan een vraag over een poster aan de muur, of over een foto op de kast, een interessant verhaal naar boven brengen over iemand of iets met een speciale betekenis voor het kind en het gezin.

Bij Jimmy hangt een poster van Kevin de Bruyne aan de muur. Ik vraag hem wat hij vindt van deze voetballer. Jimmy legt uit dat Kevin vroeger op school ook een kort lontje had, net als hijzelf, maar dat hij uiteindelijk de beste voetballer is geworden die Jimmy kent. En natuurlijk zou hij ook best de 350.000 euro per week willen verdienen die Kevin krijgt. Het contrast met zijn eigen budget, waar hij vaak halverwege de week al doorheen is, kan niet groter zijn.

Tijdens de pandemie zijn we ook aan de kinderen of de jongeren gaan vragen of er een bepaald object is dat ze nu vaker gebruiken, of dat recent een andere betekenis heeft gekregen, en zo ja, of ze ons dat dan willen laten zien. We hebben ontdekt dat dit een goede manier is om te komen tot 'spreken door doen' (language in action) en dat het kinderen ertoe aanzet om een inventieve respons te tonen op de moeilijkheden die ze ondervinden, en om zich te laten zien als actieve spelers in hun leven, zonder dat ze daar heel expliciet over hoeven te worden.

Lesley (9 jaar) woont in een jeugdinrichting, maar vanwege de lockdown krijgt ze van de rechter toestemming om deze periode bij haar moeder door te brengen. Als ik haar vraag naar een object dat ze anders is gaan gebruiken, rent ze weg van het beeldscherm en hoor ik plotseling een hoop lawaai op de achtergrond. Ze komt weer in beeld met een pizza-snijmachine. Sinds het begin van de lockdown maakt zij samen met haar moeder elke vrijdag zelf pizza's. Die momenten van pizza maken noemt ze de 'zonnige moeder-dochtermomenten'.

In de 'landingsfase' is het ook belangrijk om te informeren of er mensen meeluisteren op de achtergrond, en wie er eventueel nog binnen zou kunnen komen en ook aan het gesprek zou kunnen deelnemen. Is het kind, of het gezin, op een veilige en comfortabele plek waar ze onbekommerd kunnen praten? We vragen de kinderen nu weleens om op het beeldscherm (via de whiteboardfunctie) een plattegrond van hun huis te tekenen en ons erin rond te leiden, zodat ze ons kunnen laten zien waar hun lievelingsplekken zijn, waar ze zich graag verstoppen, waar ze blij of juist verdrietig geweest zijn, waar ze zich prettig voelden, of waar ze juist gevoelens van wanhoop of haat hebben beleefd.

Efecan tekent zijn slaapkamer. Hij legt uit wat zijn bed voor hem betekent: het is een verdrietige plek, omdat hij 's avonds zijn vader en moeder erg mist, maar het is ook een fijne plek, omdat hij daar met zijn teddybeer kan praten. En het is zelfs een plek waar hij blij van wordt, omdat hij op dit bed heeft geleerd om een perfecte koprol te maken.

In de 'landingsfase' is de speelse benadering bedoeld om bepaalde relationele aspecten aan het licht te brengen en om een veilig platform te creëren vanwaar allerlei lastige zaken aan bod kunnen komen. 


\section{Een brede visie houden op 'kind en gezin': het beeldscherm als blikverruimer}

Er bestaat altijd een risico dat de zichtbare interactiepatronen, die via het beeldscherm geobserveerd kunnen worden, en de manier waarop de verhalen naar voren komen, gezien worden als de enige verklaring voor alle mogelijke problemen. De problemen, en verklaringen daarvoor, dreigen daardoor gesitueerd te worden binnen het kind, binnen het gezin, en binnen hun communicatie- en interactiepatronen. De kinderen zelf, en ook andere betrokkenen, beginnen de behandeling vaak vanuit dit soort reductionistische, in steen gebeitelde conclusies over de problemen en hun oorzaken. Als we zelf ook vanuit dit perspectief gaan opereren, missen we soms de kans om het gesprek een nieuwe wending te geven.

We hebben dan ook extra actie moeten ondernemen om ervoor te zorgen dat we een breed perspectief houden op de problematiek, op het kind en het gezin, en ook op het netwerk eromheen. Op de achtergrond zijn er immers legio mensen, groepen, instellingen en gemeenschappen die in gesprek zijn met de kinderen en over de kinderen. Verder komen de woorden van onze cliënten altijd voort uit een bepaalde positie, en of dit nu een achterstandspositie of een geprivilegieerde positie betreft, het gaat altijd om een perspectief dat is ingebed in een sociaal-culturele context. Door in de gesprekken actief te sturen op het zichtbaar maken van de achterliggende netwerken hebben we een belangrijk tegengif gevonden voor onze neiging om alleen te focussen op wat zich op de voorgrond afspeelt.

Via het beeldscherm laat ik Lesley zien hoe je een blad papier in verschillende stukjes kunt scheuren (geïnspireerd op een oefening van Burnham 2009). Ik vraag haar om voor iedereen een stukje papier te pakken: voor zichzelf, voor de andere mensen binnen haar bubbel, en voor degenen die de afgelopen tijd belangrijk voor haar zijn geweest. Op elk stukje papier moet een naam komen, en daarna mag ze de papiertjes versieren en vouwen op de manier die haar het beste lijkt. Ze gaat er enthousiast mee aan de slag en wappert geregeld met een stukje papier voor het scherm. Haar moeder krijgt een papiertje vol met roze hartjes. Het papiertje voor haarzelf is aan de buitenkant roze gekleurd, maar op de binnenkant staat een traan, omdat ze weet dat ze slechts tijdelijk in de nabijheid van haar moeder kan zijn. Ze maakt ook versierde papiertjes voor haar kat en voor haar knuffelbeer. Als ze klaar is met haar collectie vraag ik haar om een ander blad papier te pakken en haar eigen papiertje daar op te leggen. Dan vraag ik haar om de papiertjes van de anderen eromheen te leggen, telkens op een afstand die ze zelf prettig vindt (fig. 1).

Kinderen of jongeren kunnen dus achter hun computer aan het werk gezet worden door ze te vragen om hun relatienetwerk op een speelse manier concreet vorm te geven. Ze kunnen dit doen met behulp van stukjes papier, post-its, allerlei speelgoeddieren of andere kleine objecten die ze zelf kiezen (Vermeire 2019). Het is ook mogelijk om het allemaal op het beeldscherm te tekenen, via de whiteboardfunctie. Zo bepalen ze zelf wat ze ons willen laten zien en met ons willen delen. En, belangrijker nog, hun aandacht (en die van ons) wordt zo afgeleid van henzelf en gericht op de netwerken waar ze deel van uitmaken. Door het stellen van vragen kunnen we ze helpen om zich duidelijk bewust te worden (to 're-member', White 2007) van hun relaties en van de netwerken waarin ze betrokken zijn. Dit kan ook 


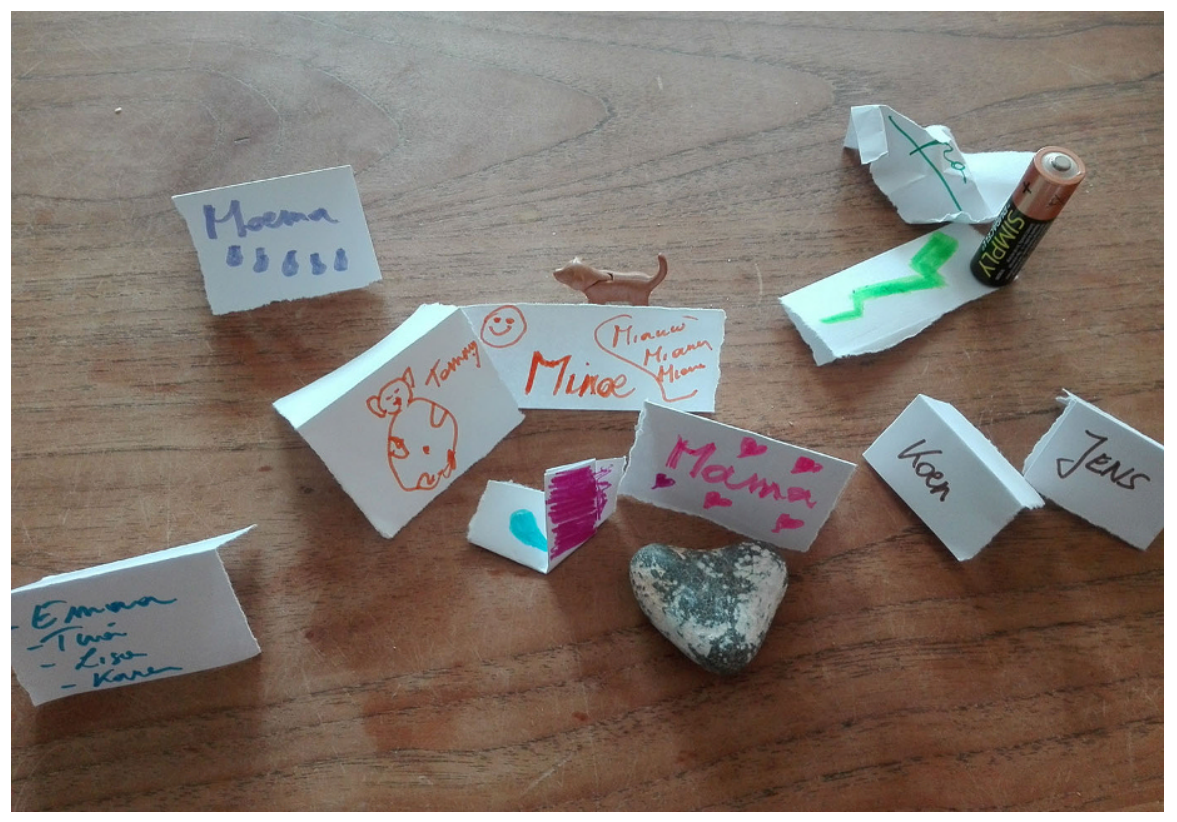

Figuur 1 Het relatienetwerk van Lesley

iets zichtbaar maken van hun sociale vaardigheden en zelfs van de invloed van het bredere sociale netwerk om hen heen (Burnham 2009).

Terwijl Lesley bezig is om met de papiertjes haar netwerk vorm te geven, vraag ik aan haar of ze vindt dat de rechter er ook bij hoort, omdat hij een rol speelt in haar leven en belangrijke beslissingen over haar neemt. Ik vraag me ook hardop af wat ze ervan vindt dat haar huidskleur anders is dan die van haar moeder en de meeste andere mensen in haar netwerk, omdat haar vader van Congolese afkomst is.

We kunnen ook externaliserende vragen stellen, zoals: Zijn er obstakels of belemmeringen in je netwerk waar je je zorgen over maakt?

Als ik haar vraag naar obstakels in haar netwerk, verdwijnt ze weer, om even later terug te komen met een batterij. Ze legt de batterij bij haar vaders verfrommelde papiertje, dat aan de rand van haar relatienetwerk ligt. 'Als hij dronken is zijn zijn batterijen bijna leeg.'

Als ik haar vraag of ze nog speciale lijnen wil tekenen tussen de verschillende mensen, tekent ze een bliksemschicht tussen haar vader en haar moeder. Deze 'destructieve bliksem' heeft in haar leven en in het gezin veel kapotgemaakt.

\section{Steun en solidariteit via een team van supporters}

Het feit dat we op deze manier relaties en netwerken zichtbaar kunnen maken, is niet altijd een garantie dat we niet vastlopen in een beeldschermsessie. Het gebeurt weleens dat we achter de computer vervallen in 'simpele vraag-en-antwoord- 
gesprekken' waarin niets nieuws aan de orde komt. Hoe vaker het kind aan de andere kant van het scherm zwijgt en alleen nog maar de schouders ophaalt, des te meer zijn we geneigd terug te vallen op de rol van expert of verzorger. Als we 'elkaar via het scherm in de ogen kijken', zijn er voor onze standaard 'vragen' en 'verklaringen' kennelijk minder 'ontsnappingsmogelijkheden', terwijl de eigen ervaringen van de kinderen, hun verhalen, ideeën en gedachten niet geuit worden (Vermeire 2017).

\begin{abstract}
Wanneer Lesley klaar is met het uitbeelden van haar netwerk van belangrijke en betekenisvolle mensen, vraag ik haar wie ze zou willen uitnodigen om bij onze sessies aanwezig te zijn, 'in het echt' of 'net alsof', en van wie ze steun denkt te kunnen verwachten als we goede raad of inspiratie nodig hebben, of als we er zelf niet uit komen. Ze kiest dan onmiddellijk voor haar oma, omdat die echt goed is met kinderen.

En ze vraagt of haar knuffelbeer Tommy ook bij het team mag. Hij is degene die haar het beste kent en hij is het meest betrouwbaar. En Shirley, een meisje uit haar woongroep, is ook belangrijk, want die kan haar aan het lachen maken. Als de spanning te hoog oploopt tijdens onze sessies, dan kan zij er grapjes over maken.
\end{abstract}

De actieve en speelse manier waarop we belangrijke derden en netwerkfiguren bij onze sessies betrekken blijkt een probaat middel om te voorkomen dat we verzanden in louter tweegesprekken. Niet alleen 'echte' mensen (familie of vrienden) kunnen lid zijn van het team van supporters, maar ook knuffelbeesten, huisdieren, en pop- of sport-idolen kunnen het team versterken. In plaats van toe te geven aan de neiging om meteen zorgen of verklaringen te uiten, zetten we het gesprek even op pauze en creëren we ruimte om zogenaamd een van deze extra teamleden uit te nodigen om zich bij de sessie aan te sluiten, waarbij we bijvoorbeeld een foto van die persoon op het scherm tonen. We onderzoeken ook wie in staat zou zijn om welke hulp te bieden, en we bedenken samen bij welk onderwerp we iemand willen uitnodigen en wat daarvoor het beste moment zou zijn.

\footnotetext{
Op een gegeven moment zijn Lesley en ik in gesprek over de vele meningsverschillen en ruzies die er tussen haar vader en moeder geweest zijn. Ik vraag me hardop af of ze zichzelf heeft kunnen troosten in die periode van haar leven. Ze haalt haar schouders op en zegt: 'Nee, dat kon ik niet'.

Ik stel voor dat ze haar knuffelbeer erbij pakt om hem een paar vragen te stellen. Tommy verschijnt voor het scherm en hij beantwoordt mijn vragen door met zijn hoofd ja te knikken of nee te schudden. Soms geeft Lesley zelf antwoord, sprekend vanachter haar knuffel, met 'de stem van een echte beer'. Tommy kan zich herinneren hoe Lesley zichzelf soms toch kon troosten.
}

Door de beer in beeld te brengen en hem vragen te stellen, terwijl Lesley zich achter hem verschuilt, ontstaat er een gesprek tussen drie personen, waardoor ik kan vermijden met haar in een zinloze rondedans terecht te komen. Zo worden de leden van het supportersteam assistenten in de behandeling. Via hen kunnen we de 'ervaringsdeskundigheid' van het kind aanboren en therapeutisch inzetten.

Therapeutisch gezien is het mogelijk om nog een stap verder te gaan door op een speelse manier te informeren bij deze fantasie-supporters wat het kind voor hén betekent, ofwel wat het kind heeft bijgedragen aan hun leven. Als kinderen erachter komen dat ze zelf van betekenis zijn in de levens van anderen, krijgen 
ze een gevoel van relationele controle, en betekent dat vaak een impuls voor de ontwikkeling van een positieve identiteit, zelfvertrouwen en bevredigende relaties (De Mol et al. 2018).

\section{Speelsheid als startpunt voor een serieuze exploratie en een rijk narratief}

Vanuit het brede palet aan online opties dienen zich nieuwe manieren aan om met de kinderen in gesprek te raken, en te onderzoeken met welke zorgen, problemen, obstakels en moeilijkheden ze te maken hebben. We vragen ze bijvoorbeeld om op het scherm een afbeelding te maken van hun zorgen of problemen (Vermeire et al. 2018). Stap voor stap, en zo direct mogelijk vanuit hun eigen ervaringen, maken we dan samen op het whiteboard van ons gedeelde beeldscherm een tekening van de problemen, en proberen we die zo uitgebreid mogelijk te beschrijven. Soms vragen we de kinderen om in hun kamer, of hun huis, een voorwerp te zoeken dat volgens hen past bij hun ervaring. En soms laten we ze de tafel naast ons zien, waar ze dan een passend voorwerp kunnen kiezen uit een hele collectie objecten die er staan uitgestald (waaronder Russische poppetjes, autootjes, Skylanders, dino's en duploblokken). Ook zoeken naar afbeeldingen van voorwerpen op internet kan tot verrassende resultaten leiden. Als er ouders of andere gezinsleden bij het gesprek zijn betrokken, dan mogen zij het kind helpen, of mogen ze een geschikt voorwerp uitzoeken voor zichzelf of voor het hele gezin.

In de eerste maanden van de pandemie hebben we aan het begin van zo'n verkennende sessie vaak vragen gesteld als: 'Hoe is het coronavirus in jouw leven beland?' en 'Wat heeft corona veranderd aan de problemen die er al waren?' En ook hebben we de kinderen gevraagd corona uit te beelden door er een plaatje bij te zoeken of er een tekening van te maken.

Efecan kiest voor de triceratops, die hij de 'corona bulldozer' noemt. Met zijn drie horens kan dit beest zijn driftbuien verergeren en de afstand tot zijn moeder vergroten.

Het effect van samen naar een tekening op het whiteboard kijken, of naar een voorwerp op het scherm, is dat de kinderen minder gauw het gevoel krijgen dat ze geanalyseerd of verhoord worden. Het maakt het ook makkelijker om bepaalde problemen te onderzoeken en daarbij te achterhalen wat er in het verleden is gebeurd en welke invloed dat heeft gehad op de cliënt zelf en op zijn of haar leven en relaties. De tekeningen, plaatjes en objecten kunnen de kinderen helpen om hun ervaringen te verwoorden, en leiden tot gedetailleerde verhalen en nieuwe betekenissen. Die concrete dingen vormen zo de stapstenen vanwaar ze hun ervaringen en verhalen delen met het hele gezin en met de directe omgeving. 


\section{De online dans van relaties}

Lisa (13) woont in een klein dorp, samen met haar ouders, haar jongere zusje (7) en haar oudere broer (16). Ze heeft last van dyscalculie en kreeg op haar tiende te horen dat ze aan diabetes lijdt. Een jaar geleden ging ze naar de middelbare school en dat betekende dat ze al haar vriendjes en vriendinnetjes van de basisschool kwijtraakte. Nu heeft ze sinds drie maanden elke schooldag 'hoofdpijn' en blijft ze steeds vaker thuis. Haar ouders maken zich zorgen over haar negatieve gedachten en depressieve stemming. Als Lisa op het beeldscherm verschijnt, zit ze op haar bed, tussen haar vader en moeder in. Nog voor ik iedereen welkom kan heten, begint Lisa te huilen en zegt ze: 'Ik ben een misbaksel'. Haar vader legt een arm om haar heen en zegt dat ze zulke dingen niet moet zeggen. Ook de moeder krijgt tranen in haar ogen, waarna de vader zich tot mij wendt en uitlegt wat er 'echt aan de hand is'.

Bij de online gezinssessies is het de bedoeling dat we het hele gezin 'in beeld' brengen, zodat de gezinsleden hun verhalen en opvattingen met elkaar delen, en niet ieder afzonderlijk met de therapeut in gesprek gaan. De dingen die ouders zeggen en doen zijn mede gebaseerd op maatschappelijke noties, zoals: 'Als ouder probeer je je kind te beschermen tegen narigheid', of 'Als ouder weet je wat er in je kind omgaat (alsof ouders het kind 'van binnen' kennen) en moet je aan een therapeut kunnen uitleggen wat er aan de hand is'. We kunnen de invloed van het sociale discours ook herkennen aan de manier waarop kinderen zich manifesteren in het gesprek met hun ouders. Die sociale noties leiden vaak tot patronen van spreken en luisteren die vanzelfsprekend worden gevonden (Freedman 2014) en waarin niets nieuws wordt verteld en niets nieuws wordt gehoord. Deze valkuil laat zich in gesprekken via het beeldscherm nog sterker gelden, en daarom hebben we onze digitale sessies vanaf het allereerste begin anders moeten structureren (Freedman 2014).

Ik onderbreek Lisa's vader en vraag aan de ouders of ze het goed vinden dat ik hun dochter een kort interview afneem, omdat ik haar hoorde zeggen dat ze 'een misbaksel' is. Ik geef aan dat ik graag zou willen weten wat ze ermee bedoelt en waarom ze het zegt. Het lijkt immers nogal belangrijk voor haar. Dan vraag ik Lisa of zij het goed vindt dat ik haar een paar vragen stel. Ze tilt haar hoofd op en kijkt me een beetje nieuwsgierig aan. Ik vraag haar of ze het een goed idee vindt om haar ouders te vragen hun oren dicht te houden, omdat $i k$ heb gemerkt dat zij het moeilijk vinden om haar die uitdrukking 'ik ben een misbaksel' te horen gebruiken. Dan glimlacht Lisa even.

Ik sla een enigszins 'strenge' toon aan en vraag de ouders om tijdens het korte interview hun handen over hun oren te houden, voor ongeveer 5 à 10 minuten.

Ik beloof dat we hun daarna zullen laten weten wat we ontdekt hebben. De ouders volgen mijn verzoek op. Ik geef ze een knipoog (wat Lisa ook kan zien) en ik check of ze nog iets kunnen horen. Ze kunnen ons nog steeds horen, maar ik zeg dat dat geen probleem is, zolang ze zich maar niet in het interview mengen.

Onze ervaring is dat het van achter een beeldscherm behoorlijk lastig kan zijn om een gesprek te (her)structureren op een respectvolle manier, met name respectvol jegens ieders positie en betrokkenheid in de gezinsrelatie. Maar door oog te hebben voor wat we op het scherm zien gebeuren en toestemming te vragen om de sessie op een andere - misschien zelfs een beetje 'gekke' manier - te beginnen, hebben we 
ruimte gecreëerd voor een speelsere structurering en verbinding. Op een speelse, indirecte manier hebben we de gezinsleden ertoe aangezet om nieuwsgierig naar elkaar te worden, en notie te nemen van elkaars zorgen, moeilijkheden, intenties, ideeën, wensen en verlangens. Op deze manier worden ze elkaars getuigen en kunnen ze in principe, en hopelijk ook daadwerkelijk, erkennen wat er leeft in de gedachten en gevoelens van de ander.

Lisa zit rechtop voor het scherm, helemaal klaar om geïnterviewd te worden. Ze vertelt me dat ze te vroeg is geboren, dat ze kampt met leerproblemen en, alsof dat nog niet genoeg is, dat ze ook nog eens diabetes heeft. En als ik misschien had gedacht dat dat alles was... dan had ik het mis, want dit jaar was ze ook nog naar een andere school gegaan, naar de stomste school en de stomste klas van de wereld. Ik vraag wat haar het sterkst het gevoel geeft een misbaksel te zijn. Daarop zegt ze dat zich een buitenbeentje voelt in haar klas. Sommige leerlingen maken gekke opmerkingen over haar katheter en één meisje had zelfs gevraagd of ze soms een 'alien' was. Ze zegt dat ze haar hele leven tegen de diabetes zal moeten vechten.

Na een tijdje verzoek ik de ouders of ze hun handen van hun oren willen halen en vraag $i k$ of ze iets hebben gehoord dat hun verrast of geraakt heeft, of wat nieuw voor hen is. Ook vraag ik of dit overeenkomt met hun eigen ervaringen en wat ze voor zichzelf uit Lisa's verhaal hebben gehaald. Is er misschien iets waar ze op willen reageren? Haar moeder zegt dat ze geraakt is door Lisa's protest en boosheid, en haar vader antwoordt dat hij wenste dat hij haar van de diabetes af kon helpen.

Deze sessies zijn gebaseerd op de veronderstelling dat iedereen die erbij aanwezig is een waardevol gezichtspunt heeft, en dat de naast elkaar gelegde gezichtspunten bij eenieder tot een groter en rijker begrip kunnen leiden van de situatie waarin het kind verkeert en de moeilijkheden die het ervaart.

\begin{abstract}
Als we Lisa en haar ouders afwisselend interviewen en observeren, wordt het steeds duidelijker dat Lisa heel bang is voor de diabetes, vooral voor de injectienaalden, en dat ze ook boos is vanwege de beperkende effecten op haar leven en op haar omgang met anderen. Tegelijkertijd hadden haar ouders gehoopt dat het voor Lisa makkelijker zou worden als ze haar voorhielden dat ze zich 'eroverheen moest zetten' en moest leren zich 'erbij neer te leggen'.
\end{abstract}

\title{
Een theater van mogelijkheden: de online gezinsquiz
}

Langzamerhand worden de gezinsleden steeds nieuwsgieriger naar elkaars verhalen.

Als ik haar nieuwsgierigheid bemerk, vraag ik aan Lisa of ze denkt dat haar ouders weten hoeveel last ze heeft van haar angst en boosheid, en of ze haar ouders daarover een paar vragen wil stellen. Misschien in de vorm van een slaapkamerquiz? En wil ze haar ouders dan punten geven voor hun antwoorden?

Dit proces van 'opnieuw met elkaar verbinden' voorziet niet alleen in nieuwe manieren om met elkaar te praten en naar elkaar te luisteren, maar creëert ook een geïmproviseerde ruimte binnen de sessie. Zo kan online therapie, zoals Wilson (2005) zegt in zijn metafoor, een theater van mogelijkheden worden, waarin 
iedereen verschillende rollen speelt en van plek verwisselt, waardoor nieuwe gespreksruimte ontstaat die nieuwe vragen en antwoorden voortbrengt (Vermeire 2017).

Lisa en ik worden quizmasters. De ouders zijn de quizkandidaten en zij worden naar de breakout-room gestuurd met de instructie om na te denken over de vragen die ze aan Lisa willen stellen in de volgende ronde van de gezinsquiz. De eerste vragen die Lisa en ik bedenken zijn: 'Hoe boos denk je dat ik ben op een schaal van 0 tot 10?' en 'Hoe erg denk je dat ik de katheter vind, op een schaal van 0 tot 10?'

Als de ouders terugkomen vindt iedereen het een beetje 'spannend' en zijn ze allemaal duidelijk betrokken bij de beeldschermsessie. Lisa gaat helemaal op in haar rol als quizmaster. Ze draagt haar ouders op om de vraag eerst met elkaar te bespreken voordat ze antwoord geven. Na elk antwoord van de ouders vraag ik hoeveel punten Lisa ervoor geeft. Vervolgens is het de beurt aan de ouders, die willen weten hoe ze Lisa beter kunnen helpen met haar angst en frustraties.

Volgens McNamee (2000) wordt creativiteit in therapie ook wel 'sociale poiesis' genoemd, omdat er tussen mensen dingen gebeuren die door hen gezamenlijk gecreëerd worden. Daardoor kan er binnen de onderlinge relaties een nieuwe realiteit ontstaan waarin meer steun en betekenis wordt ervaren, en die bij alle gezinsleden het gevoel vergroot zelf invloed te hebben op hun relaties. Dat wil zeggen dat de cliënten ervaren dat ze in hun eigen leven een sturende rol hebben die doorwerkt in hun relaties en ook in verbinding staat met de bredere sociale context van hun acties (De Mol et al. 2018)

Door de vragen die ze mag stellen is Lisa nieuwsgieriger geworden naar de ervaringen van de ouders met haar diabetes en haar gevoel een 'misbaksel te zijn'. Ze deelt punten uit als ze denkt dat haar ouders een eerlijk antwoord hebben gegeven. In de periode daarna bedenken de gezinsleden tussen de sessies door telkens vragen waarmee ze elkaar bij de volgende afspraak kunnen verrassen. Daarbij worden punten uitgedeeld op basis van de originaliteit en kwaliteit van elke vraag.

\section{Verbinding maken met het bredere netwerk en de sociale context}

Een belangrijk doel van onze systemische benadering is om kinderen, jongeren en gezinnen opnieuw in verbinding te stellen met de gemeenschap en de bredere netwerken waartoe ze behoren. Ook bij online therapie maakt het een groot verschil of de aandacht alleen gericht is op de ervaringen, de problemen, de reacties en de oplossingen voor moeilijkheden binnen het gezin, of ook op de veelstemmigheid, het multiversum van stemmen die het gezin omringen (Vermeire 2020).

Als ik Lisa vraag of ze andere kinderen, jongeren of volwassenen kent die te kampen hebben met diabetes en de effecten ervan, en of ze weet hoe die ermee omgaan, dan heeft ze daar geen antwoord op. Ik nodig haar uit om een vragenlijst te maken voor mensen met diabetes, en daarin alle vragen op te nemen die ze altijd al graag had willen, maar nooit had kunnen of durven stellen (Vermeire 2017, 2020). Indirect doet ze zo onderzoek naar haar eigen zorgen. 'Ben je weleens boos op de diabetes?', 'Denk je weleens "Waarom" of "Waarom ik”?', 'Ben je bang voor de pijn?', 'Hoe reageren andere mensen erop?'. Ook haar ouders 
bedenken enkele vragen voor de lijst. Ik gebruik de vragenlijst om online interviews af te nemen bij mensen met diabetes uit mijn eigen netwerk die het geen probleem vinden Lisa's vragen te beantwoorden (een collega, een kind en een jongere). Een week later laat ik Lisa en haar ouders online naar de opgenomen interviews kijken. Lisa is heel opgelucht als blijkt dat een 40-jarige vrouw met diabetes ook nog bang is voor injectienaalden, en ze heeft veel interesse in de manier waarop een 17-jarige jongen manieren heeft gevonden om te dealen met allerhande domme opmerkingen die hij soms hoort. En haar moeder begint te lachen als ze hoort hoe de moeder van de 40-jarige vrouw nog steeds checkt of de bloedsuiker bij haar dochter niet te laag is en hoe vervelend de dochter dat vindt.

Deze verhalen betekenen voor Lisa een herkenning en erkenning van de kennis en vaardigheiden die ze al heeft opgedaan. Een van de doelstellingen van deze manier van werken is dat Lisa en haar ouders het gevoel krijgen deel uit te maken van een belangrijke groep lotgenoten en van de bredere gemeenschap om hen heen (Vermeire 2020).

\section{Draden weven en ontdekkingen verankeren}

Een van de risico's van online therapie gedurende de eerste weken van de pandemie was dat de sessies louter geïsoleerde gesprekken zouden worden waarin gecheckt wordt 'of alles nog goed gaat tijdens de lockdown', zonder dat dit verder iets bijdraagt aan het therapeutisch proces. In de hoop 'verbindingsdraden' tussen de sessies te kunnen weven, hebben we online opslagboxen gemaakt of dropboxbestanden gedeeld om dingen uit de sessies in te bewaren, zoals tekeningen en afbeeldingen, verzamelde verhalen, teams van supporters, en ook waardevolle ideeën of nieuwe perspectieven die in de gesprekken naar voren zijn gekomen. De ideeën kunnen gedocumenteerd worden in de vorm van een brief, een 'lijst met ontdekte vaardigheden', een 'herinneringskaart', of een afbeelding van 'mijn kring'. De documentatie helpt om bepaalde woorden, zinnen, verklaringen en ideeën in gedachte te houden (White en Epston 1990) en versterkt de samenwerking tussen het kind, het gezin en de therapeut. Bovendien kan alles wat is opgeslagen online geraadpleegd worden tussen de sessies door, zodat de therapie een continu proces wordt. De gezinsleden kunnen op elk gewenst moment de verzamelde documenten herlezen, hervertellen, herontdekken en eventueel opnieuw bewerken. En op den duur vormt zich zo een zichtbare en tastbare afspiegeling van al het werk dat samen is verzet.

\section{Epiloog}

De online trajecten die we tijdens de coronapandemie met onze cliënten hebben afgelegd, hebben we als heel leerzaam ervaren. Net als veel van onze collega's zagen we ons in het begin gedwongen om onze comfortzone te verlaten, maar uiteindelijk is gebleken dat de technische, digitale omgeving van online therapie geen belemmering hoeft te vormen voor een systemische benadering vol speelsheid en samenwerking. Door de puzzelstukjes net weer anders te leggen, en geïnspireerd 
door de ideeën van Koestler over creativiteit, hebben we nieuwe en verrassende therapeutische werkvormen ontwikkeld, of beter gezegd, samen mogelijk gemaakt.

Ook in face-to-face therapie betekent speelsheid vaak een stap in een minder comfortabele richting. Bij onze online behandelsessies, profiteren we echter van de mogelijkheid om te werken in een therapeutische omgeving die bekend en vertrouwd is voor de cliënt en tegelijk een gevoel van nieuwsgierigheid en avontuur opwekt. De kinderen en andere gezinsleden kunnen in hun vertrouwde omgeving verblijven, met al hun speelgoed en eigen spullen, en ze kunnen daardoor op een speelse manier meedoen vanuit hun eigen leef- en gedachtewereld.

We realiseren ons dat de weg die we zijn ingeslagen verdere exploratie en ontwikkeling vereist, zeker wanneer straks de bijzonder moeilijke omstandigheden van nu niet meer aan de orde zijn. We zijn ervan overtuigd dat veel van onze collega's erin geslaagd zijn om in hun online sessies nieuwe 'mogelijke werelden' te scheppen, die waarschijnlijk weer anders zijn dan die van ons. Interessant is dat jongeren online therapie prefereren, als ze er eenmaal aan gewend zijn. En het is ook opvallend dat vaders online vaak minder moeite hebben met hun deelname aan de behandeling. We denken dat het voor therapeuten zinvol is om de ontwikkelde online behandelmethoden die goed blijken te werken te behouden, en om hun face-to-face werk te verrijken met de nieuwe ideeën die zijn voortgekomen uit de periode van 'verplichte' online therapie.

Ten slotte zijn we onze cliënten erg dankbaar dat ze in deze moeilijke tijden hun vertrouwen in ons hebben bewaard en het voor ons mogelijk hebben gemaakt om ons therapeutische werk ondanks de beperkende omstandigheden voort te zetten.

\section{Literatuur}

Anderson, A., \& Gehart, D. (2007). Collaborative therapy. Relationships and conversations that make a difference. New York, London: Routledge.

Burnham, J. (2009). Workshop: creativity and play in conversations with children, adolescents and their families. Antwerp, 12 jun 2009.

Carr, A. (2012). Family therapy. Concepts, process and practice (3e druk.). Oxford: Wiley-Blackwell.

Cecchin, G. (1987). Hypothesising, circularity and neutrality revisited: an invitation to curiosity. Family Process, 26, 405-413.

Cecchin, G., Lane, G., \& Ray, W. (1992). Irreverance: a strategy for therapist's survival. London: Karnac.

Freedman, J. (2014). Witnessing and positioning: structuring narrative therapy with families and couples. The International Journal of Narrative Therapy and Community Work, 1, 11-17.

Hertlein, K., Blumer, M.L.C., \& Mihaloliakos, J.H. (2015). Marriage and family counselors' perceived ethical issues related to online therapy. The Family Journal: Counseling and Therapy for Couples and Families, 23(1), 5-12.

Koestler, A. (1964). The act of creation. London: Hutchinson \& Co.

Madsen, W.C. (2007). Collaborative therapy with multi-stressed families. New York, London: Guilford.

Madsen, W.C., \& Gillespie, K. (2014). Collaborative helping. A strengths framework for home-based services. Hoboken, New Jersey: John Wiley \& Sons.

McNamee, S. (2000). The social poetics of relationally engaged research: research as conversation. In K. G.S. Deisslerand McNamee (red.), Philosophy in therapy: the social poetics of therapeutic conversations. Heidelberg: Carl-Auer.

De Mol, J., Reijmers, E., Verhofstadt, L., \& Kuczynski, L. (2018). Reconstructing a sense of relational agency in family therapy. Australian \& New Zealand Journal of Family Therapy, 39, 54-66. 
Rober, P. (1999). Reflections on ways to create a safe therapeutic culture for children in family therapy. Family Process, 37, 201-213.

Rober, P., Van Tricht, K., \& Sundet, R. (2020). 'One step up, but not there yet': using client feedback to optimise the therapeutic alliance in family therapy. Journal of Family Therapy. https://doi.org/10. $1111 / 1467-6427.12292$.

Shotter, J. (2012). Ontological social constructionism in the context of a social ecology: The importance of our living bodies. In A. T. Lockand Strong (red.), Discursive perspectives in therapeutic practice (pag. 83-105). Oxford: Oxford University Press.

Simpson, S., Richardson, L., Pietrabissa, G., Casrelnuovo, G., \& Reid, C. (2020). Videotherapy and therapeutic alliance in the age of COVID-19. Clinical Psychology and Psychotherapy. https://doi. org/10.1002/cpp. 2521.

Vermeire, S. (2017). What if... I were king? Playing with roles and positions in narrative conversations with children who experienced trauma. The international Journal of Narrative Therapy and Community Work, , 4, 6-17.

Vermeire, S. (2019). Genograms at the kitchen table - tea, teabags and sugar cubes: playfully working with genograms and timelines with families in transition. Context, 161, February 2019.

Vermeire, S. (2020). No child is an island: from attachment narratives towards a sense of belonging. Journal of Family Therapy, 42, 1-17.

Vermeire, S., Beckers, W., Faes, M., \& Decraemer, K. (2018). What's the problem? Children / adults turn problems inside out. Antwerpen: Interactie-Academie vzw.

White, M. (2007). Maps of narrative practice. New York: W. W. Norton.

White, M., \& Epston, D. (1990). Narrative means to therapeutic ends. New York: W.W. Norton \& Co..

Wilson, J. (2005). Engaging children and young people. In A. E. Vetereand Dowling (red.), Narrative therapy with children and their families (pag. 90-106). London: Routledge.

Wilson, J. (2007). The Performance of Practice. London: Karnac Books. 